\title{
Present Status of Marine Radioecology in Jakarta Bay
}

\author{
H. Suseno ${ }^{1 *}$, Budiawan ${ }^{2}$, Muslim $^{3}$, M. Makmur ${ }^{1}$ and M.N. Yahya ${ }^{1}$ \\ ${ }^{I}$ Center for Radiation Safety Technology and Metrology, National Nuclear Energy Agency, \\ Jl. Lebak Bulus Raya No. 49, Jakarta 12700, Indonesia \\ ${ }^{2}$ Departement of Chemistry, Faculty of Mathematics and Natural Sciences, \\ University of Indonesia, Kampus UI Depok 1642, Indonesia \\ ${ }^{3}$ Departement of Oceanography, Diponegoro University, \\ Kampus UNDIP Tembalang, Semarang 1269, Jawa Tengah, Indonesia
}

\section{ARTICLE INFO}

\section{Article history:}

Received 5 February 2017

Received in revised form 16 November 2017

Accepted 15 February 2018

\section{Keywords:}

Jakarta bay

Radioecology

${ }^{137} \mathrm{Cs}$

${ }^{239 / 240} \mathrm{Pu}$

\begin{abstract}
A B S T R A C T
Operation of nuclear facilities such as research reactor and it's supporting installation in Serpong Nuclear Area may release controlled radionuclides to Cisadane River and then it would flow to Jakarta Bay. There are limited marine radioecology studies or radionuclides monitoring at Jakarta Bay. Therefore monitoring of ${ }^{239 / 240} \mathrm{Pu}$ and ${ }^{137} \mathrm{Cs}$ was carried out from Tanjung Pasir to Tanjung Kerawang. The ERICA Assessment Tool was used to evaluate radiological risk in the marine environment of Jakarta Bay area. The ${ }^{137} \mathrm{Cs}$ concentration in sea water and sea sediments were in range of $0.17-1.17 \mathrm{~Bq} \cdot \mathrm{m}^{-3}$ and $0.34-1.21 \mathrm{~Bq} \cdot \mathrm{kg}^{-1}$, respectively. Moreover, result of ${ }^{239 / 240} \mathrm{Pu}$ measurement showed that concentration at sea water and sea sediment were range from $<$ MDA $-0.53 \mathrm{mBq} \cdot \mathrm{m}^{-3}$ and $2.64-55.70 \mathrm{mBq} \cdot \mathrm{kg}^{-1}$ respectively. The results of risk analysis were indicated that all the total dose rates per organism were millions time lower than the screening rate $\left(10 \mathrm{mGy} \cdot \mathrm{h}^{-1}\right)$.
\end{abstract}

\section{INTRODUCTION}

Jakarta Bay is located in the capes of Tanjung Pasir (west) and Tanjung Karawang (east). Land based activities mostly influences the Jakarta Bay that pollutants were transported by 13 rivers. i.e., Ciliwung, Cisadane and Angke [1,2]. The pollutants such as heavy metals, POPs, radionucides in sea water and sea sediments have potential to be bioaccumulated and then become biomagnified at higher trophic levels. Operation of nuclear facilities such as research reactor and it's supporting installation in Serpong Nuclear Area may be release controlled radionuclides to Cisadane River and then flow to Jakarta Bay. In the future, Jakarta Bay will receive more radionuclides due to the planning of contraction of Experimental Nuclear Power Plant (NPP) with its capacity of 10 MW.

Mostly focus of pollutants study in Jakarta Bay were chemical and biological contaminants

\footnotetext{
*Corresponding author.

E-mail address: henis@batan.go.id

DOI: https://doi.org/10.17146/aij.2018.606
}

$[1,3,4]$. On other hand marine radioecology studies or radionuclides monitoring in Jakarta Bay is still limited. These studies only limited marine monitoring and concerned to the distribution of natural radionuclides and ${ }^{137} \mathrm{Cs}$ on Jakarta Bay [5]. Furthermore, another study was concerned to the accumulation rate in Jakarta Bay that used ${ }^{210} \mathrm{~Pb}$ dating. These previous studies only measured the radionuclides concentration and for geochronological purpose. On other hand updating status of marine radioecology is needed to record the present level of radionuclides before the operation of experimental nuclear power plant in Serpong. The most valuable marine radioecological study for NPP siting is to find and understand about radionuclides concentration before the operation of nuclear power plants [6].

Risk assessment is also required to obtain information about the impact of the existing nuclear research reactor in Serpong to Jakarta Bay. The quantification of environmental risk regarding to radioactivity release can be estimated by using ERICA Tool, whereby a measurement of exposure 
was provided from data on dosimetry and environmental transfer [7]. ERICA Assessment Tool was used to evaluate radiological risk in the marine environment of Jakarta Bay area. ERICA (Environmental Risk from Ionizing Contaminants: Assessment and Management) provides an integrated approach to the scientific, managerial and societal issues surrounding the environmental effects of contaminants emitting ionizing radiation, with an emphasis on biota and ecosystem [7]

In this paper we report result of radionuclides monitoring and risk assessment in Jakarta Bay.

\section{EXPERIMENTAL METHODS}

The methods consist monitoring of in area Jakarta Bay from Tanjung Pasir to Tanjung Kerawang (Fig. 1) and calculation of risk assessment was done by using ERICA Tool. Sampling were carried out at 3-5 April 2016. Seawater sampling was carried out at 11 locations of Jakarta Bay (Fig. 1). Approximately up to $150 \mathrm{~L}$ of surface sea water samples were taken from each location. About $10 \mathrm{~g}$ of copper (II) and $10 \mathrm{~g}$ of potassium hexacyanoferrates (II) trihydrate nitrate salt were added to water samples and then were stirred until homogenous. After precipitate was allowed to settle for $24 \mathrm{~h}$, then it was separated from the marine water sample using paper filter. This water preparation method was conducted according to the standard procedures with minor modifications [8].

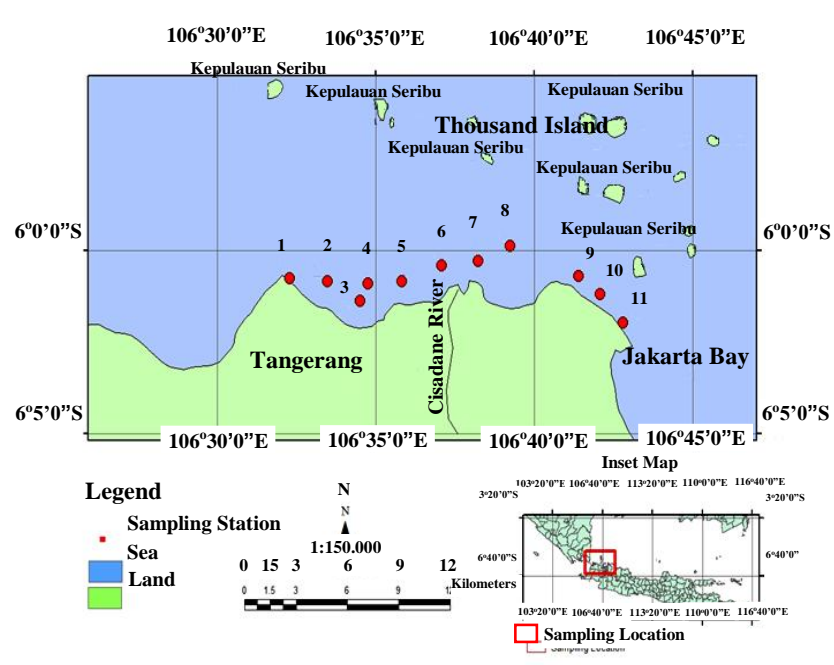

Fig. 1. Sampling locations.

The high-purity germanium (HPGe) detectors (efficiencies of 20-25\% and a fullwidth half maximum (FWHM) of $1.8 \mathrm{keV}$ for a peak of $1332 \mathrm{keV}$ of ${ }^{60} \mathrm{Co}$ Canberra GX2018, Canberra GC2020, and Ortec GMX 25P4-76) were used to measure radioactivities. Approximately $500 \mathrm{~g}$ sediment samples and $1 \mathrm{~kg}$ of dry biota were measured by direct counting method. The measurement method included detector calibration, the detector counting efficiency, the cumulative counts of the samples and background at regular intervals, smoothing of the photopeak and linear regression.

Sample preparation of plutonium isotope was used preconcentration $\mathrm{MnO}_{2}$ co-precipitate methods [9]. After radiochemical separation and electrodeposition, alpha spectrometer (Alpha analyst, Canberra) was used for ${ }^{239 / 240} \mathrm{Pu}$ analysis. Erica tool software was used to accomplished the assessment risk to the environment following a given release of radioactivity [8].

\section{RESULTS AND DISCUSSION}

The ${ }^{137} \mathrm{Cs}$ concentration in sea water of Jakarta Bay and sea sediments were in range of 0.17-1.17 Bq.m ${ }^{-3}$ and 0.34-1.21 Bq. $\mathrm{kg}^{-1}$, respectively (Table 1). This value was comparable with that in other area of Indonesia coasts. Previous study reported that ${ }^{137} \mathrm{Cs}$ in seawater from eastern and western coasts area of Indonesia were $0.12-0.32 \mathrm{~Bq} \mathrm{~m}^{-3}$ [10]. In addition in off shore of Indonesia marine water, the concentration were $<\mathrm{MDA}$ to $0.38 \mathrm{~Bq} \cdot \mathrm{m}^{-3}$ [11].

Table 1. Activity Concentration of ${ }^{137} \mathrm{Cs}$ in sea water and Sediments in several locations of Jakarta Bay

\begin{tabular}{|c|c|c|}
\hline \multirow[b]{2}{*}{ Location } & \multicolumn{2}{|c|}{${ }^{137} \mathrm{Cs}$} \\
\hline & $\begin{array}{l}\text { Sea water } \\
\left(\text { Bq. } m^{-3}\right)\end{array}$ & $\begin{array}{c}\text { Sea sediments } \\
\left(\mathrm{Bq} \cdot \mathrm{kg}^{-1}\right)\end{array}$ \\
\hline $\begin{array}{l}106^{0} 32^{\prime} 17.6^{\prime \prime} \mathrm{E}, \\
06^{0} 00^{\prime} 47.3^{\prime \prime} \mathrm{S}\end{array}$ & $1.17 \pm 0.19$ & $1.07 \pm 0.11$ \\
\hline $\begin{array}{l}106^{0} 33^{\prime} 29.8^{\prime \prime} \mathrm{E} \\
06^{0} 00^{\prime} 51.0^{\prime \prime} \mathrm{S}\end{array}$ & $1.16 \pm 0.20$ & $0.54 \pm 0.06$ \\
\hline $\begin{array}{l}106^{0} 34^{\prime} 32.6^{\prime \prime} \mathrm{E}, \\
06^{0} 01^{\prime} 24.2^{\prime \prime} \mathrm{S}\end{array}$ & $1.22 \pm 0.12$ & $0.60 \pm 0.06$ \\
\hline $\begin{array}{l}106^{0} 34^{\prime} 45.6^{\prime \prime} \mathrm{E}, \\
06^{0} 00^{\prime} 55.2^{\prime \prime} \mathrm{S}\end{array}$ & $1.12 \pm 0.16$ & $0.42 \pm 0.04$ \\
\hline $\begin{array}{l}106^{\circ} 35^{\prime} 48.3^{\prime \prime} \mathrm{E} \\
06^{\circ} 00^{\prime} 51.6^{\prime \prime} \mathrm{S}\end{array}$ & $0.27 \pm 0.03$ & $0.52 \pm 0.05$ \\
\hline $\begin{array}{l}106^{\circ} 37^{\prime} 6.443^{\prime \prime} \mathrm{E}, \\
06^{\circ} 00^{\prime} 26.6^{\prime \prime} \mathrm{S}\end{array}$ & $0.17 \pm 0.03$ & $0.34 \pm 0.05$ \\
\hline $\begin{array}{l}106^{\circ} 38^{\prime} 11.6^{\prime \prime} \mathrm{E}, \\
06^{\circ} 00^{\prime} 17.3 \mathrm{~S}\end{array}$ & $0.21 \pm 0.03$ & $0.42 \pm 0.03$ \\
\hline $\begin{array}{l}106^{0} 39^{\prime} 14.7^{\prime \prime} \mathrm{E} \\
05^{\circ} 59^{\prime} 54.9^{\prime \prime} \mathrm{S}\end{array}$ & $0.82 \pm 0.10$ & $1.21 \pm 0.09$ \\
\hline $\begin{array}{l}106^{0} 41^{\prime} 25.5^{\prime \prime} \mathrm{E} \\
06^{0} 00^{\prime} 42.8^{\prime \prime} \mathrm{S}\end{array}$ & $0.21 \pm 0.03$ & $0.73 \pm 0.09$ \\
\hline $\begin{array}{l}106^{0} 42^{\prime} 05.2{ }^{\prime \prime} \mathrm{E} \\
06^{0} 01^{\prime} 12.6 " \mathrm{~S}\end{array}$ & $0.17 \pm 0.04$ & $0.31 \pm 0.05$ \\
\hline $\begin{array}{l}106^{0} 42^{\prime} 47.4 " \mathrm{E}, \\
06^{0} 01^{\prime} 58.8^{\prime \prime} \mathrm{S}\end{array}$ & $0.27 \pm 0.05$ & $0.56 \pm 0.07$ \\
\hline
\end{tabular}

On other hand, its concentration in sea sediments was range $0.19-1.64 \mathrm{~Bq} \mathrm{~kg}{ }^{-1}$. ${ }^{134} \mathrm{Cs}$ radioisotopes were not detected in all samples taken from Jakarta 
Bay. This is a typical of the background level in Jakarta Bay due to global fallout. In contrast, even ${ }^{137} \mathrm{Cs}$ were present in very low concentration, fishes and other marine biotas have ability to accumulate from seawater [12]. The ${ }^{137} \mathrm{Cs}$ concentration in biotas from Jakarta Bay were ranged 12.40-148.40 mBq. $\mathrm{kg}^{-1}$ (Table 2). The result comparable with biota from other Indonesia coasts [13].

Table 2. Activity Concentration of ${ }^{137} \mathrm{Cs}$ in several marine biotas of Jakarta Bay

\begin{tabular}{lc}
\hline \multicolumn{1}{c}{ Biota } & $\begin{array}{c}\text { Concentration } \\
\left(\mathrm{mBq} \cdot \mathrm{Kg}^{-1}\right)\end{array}$ \\
\hline $\begin{array}{l}\text { Starry triggerfish } \\
\text { (Abalistes stellaris) }\end{array}$ & $12.4 \pm 1.2$ \\
$\begin{array}{l}\text { Crimson snapper } \\
\text { (Lutianus erythropterus) }\end{array}$ & $148.4 \pm 15.5$ \\
$\begin{array}{l}\text { Squip (Mastigoteuthis } \\
\text { flammea) }\end{array}$ & $110.4 \pm 12.1$ \\
$\begin{array}{l}\text { Mantis shrimp } \\
\text { (Odontodactylus }\end{array}$ & $20.6 \pm 2.2$ \\
$\begin{array}{l}\text { scyllarus) } \\
\text { Local crab (Portunus } \\
\text { sanguinolentus) }\end{array}$ & $22.2 \pm 2.5$ \\
\hline
\end{tabular}

Anthropogenic radionuclides could be present in Jakarta Bay because there are nuclear research activities in Serpong such as operation of nuclear research reactor, nuclear fuel installation, radioactive waste installation, radiopharmaceutical installation, etc. These research activities have potential to release amount liquid radioactive. These radionuclides are carried to Jakarta Bay coastal by Cisadane river. ${ }^{137} \mathrm{Cs} \quad\left(\mathrm{t}_{1 / 2} \quad 30\right.$ years $)$ radioisotope is fission product, usually present as simple cations and have high solubility and mobility in marine environments [9]. Furthermore, coastal sediments accumulate ${ }^{137} \mathrm{Cs}$ because contain clay mineral such as vermiculite and illite and suspended sediment irreversibly adsorb ${ }^{137} \mathrm{Cs}$ from seawater [14]. In contrast only less than $10 \%$ of ${ }^{137} \mathrm{Cs}$ transport to ocean bottom sediment [14].

The isotopes of plutonium have becomes much public and scientific concern because they have characters such as: radio and chemical toxicity and long half-live $[15,16]$. Plutonium is normally produced in reactor fuel as a mixture of isotopes. The predominant isotope, ${ }^{239} \mathrm{Pu}$, is produced by neutron capture in ${ }^{238} U$ [17]. The result of measurement showed that concentration of ${ }^{239 / 240} \mathrm{Pu}$ in sea water and sea sediment were range from $<$ MDA-0.53 mBq. ${ }^{-3}$ and 2.84-55.70 mBq. $\mathrm{kg}^{-1}$, respectively (Table 3 ). Our result of analysis indicated these concentrations of ${ }^{239 / 240} \mathrm{Pu}$ is very low compared with Pacific Ocean [18]. The extensive testing of nuclear weapon that carried out by US weapon testing program are input of plutonium to the Pacific Ocean $[18,19]$.

Table 3. Activity Concentration of ${ }^{239 / 240} \mathrm{Pu}$ in Jakarta Bay at several locations

\begin{tabular}{ccc}
\hline & \multicolumn{2}{c}{${ }^{239 / 240} \mathrm{Pu}$} \\
\cline { 2 - 3 } Location & $\begin{array}{c}\text { Sea water } \\
\left(\mathrm{mBq} \cdot \mathrm{m}^{-3}\right)\end{array}$ & $\begin{array}{c}\text { Sea sediments } \\
\left(\mathrm{mBq} \cdot \mathrm{kg}^{-1}\right)\end{array}$ \\
\hline $106^{0} 32^{\prime} 17.6^{\prime \prime} \mathrm{E}$, & $0.24 \pm 0.04$ & $9.90 \pm 1.00$ \\
$06^{0} 00^{\prime} 47.3^{\prime \prime} \mathrm{S}$ & & \\
$106^{0} 33^{\prime} 29.8^{\prime \prime} \mathrm{E}$, & $<\mathrm{MDA}$ & $2.64 \pm 0.4$ \\
$06^{0} 00^{\prime} 51.0^{\prime \prime} \mathrm{S}$ & & \\
$106^{\circ} 32^{\prime} 17.6^{\prime \prime} \mathrm{E}$, & $0.53 \pm 0.06$ & $55.70 \pm 5.80$ \\
$06^{0} 00^{\prime} 47.3^{\prime \prime} \mathrm{S}$ & & \\
$106^{\circ} 33^{\prime} 29.8^{\prime \prime} \mathrm{E}$, & $<\mathrm{MDA}$ & $34.20 \pm 3.90$ \\
$06^{0} 00^{\prime} 51.0^{\prime \prime} \mathrm{S}$ & & \\
$106^{\circ} 34^{\prime} 32.6^{\prime \prime} \mathrm{E}$, & $<\mathrm{MDA}$ & $4.12 \pm 0.50$ \\
$06^{\circ} 01^{\prime} 24.2^{\prime \prime} \mathrm{S}$ & & \\
$106^{\circ} 34^{\prime} 45.6^{\prime \prime} \mathrm{E}$, & $0.23 \pm 0.04$ & $2.84 \pm 0.30$ \\
$06^{\circ} 00^{\prime} 55.2^{\prime \prime} \mathrm{S}$ & & \\
\hline MDA < $0.1 \mathrm{mBq} \cdot \mathrm{m}^{-3}, 0.5 \mathrm{mBq} \cdot \mathrm{kg}^{-1}$ &
\end{tabular}

Isotopes of ${ }^{137} \mathrm{Cs},{ }^{239} \mathrm{Pu}$ (represent of ${ }^{239 / 240} \mathrm{Pu}$ ) were selected in the assessment and $10 \mu \mathrm{Gy} \cdot \mathrm{h}^{-1}$ was set as a dose screening value. The highest activity concentrations of ${ }^{137} \mathrm{Cs}$ and ${ }^{239} \mathrm{Pu}$ in the seawater and sediments were input into the assessment. Assessment were performaned by completing of the Tier 2. The default value in ERICA was set for radionuclides concentration in environment, distribution coefficient $(\mathrm{Kd})$, concentration ratio (CR), dose conversion coefficients, uncertainty factor and occupancy factors. Moreover, value of weighting factors for low beta, beta/gamma and alpha were set to 3,1 and 20, respectively. The results of risk analysis are listed in Table 4. These indicated that all the total dose rates per organism were lower than the screening rate $\left(10 \mu \mathrm{Gy} \cdot \mathrm{h}^{-1}\right)$.

Table 4. ERICA tool Tier 2 assessment for Total dose rate in several marine biotas of Jakarta Bay

\begin{tabular}{|c|c|c|c|}
\hline \multirow[b]{2}{*}{ Biota } & \multicolumn{2}{|c|}{ Total Dose rate } & \multirow{2}{*}{$\begin{array}{c}\text { Screening } \\
\text { Value } \\
\left(\mu \mathrm{Gy} \mathrm{h}^{-1}\right)\end{array}$} \\
\hline & $\begin{array}{c}{ }^{137} \mathrm{Cs} \\
\left(\mu \mathrm{Gy} \mathrm{h}^{-1}\right)\end{array}$ & $\begin{array}{c}{ }^{239} \mathrm{Pu} \\
\left(\mu \mathrm{Gy} \mathrm{h} \mathrm{h}^{-1}\right)\end{array}$ & \\
\hline Benthic fish & $1.79 \mathrm{E}-4$ & $5.57 \mathrm{E}-5$ & $1.00 \mathrm{E} 1$ \\
\hline Benthic mollusc & $1.83 \mathrm{E}-4$ & $1.75 \mathrm{E}-5$ & $1.00 \mathrm{E} 1$ \\
\hline Crustacean & $1.64 \mathrm{E}-4$ & $2.54 \mathrm{E}-6$ & $1.00 \mathrm{E} 1$ \\
\hline Macroalgae & $2.01 \mathrm{E}-4$ & $6.52 \mathrm{E}-5$ & $1.00 \mathrm{E} 1$ \\
\hline Pelagic fish & $1.92 \mathrm{E}-5$ & $5.57 \mathrm{E}-5$ & $1.00 \mathrm{E} 1$ \\
\hline Phytoplankton & $5.74 \mathrm{E}-7$ & $1.91 \mathrm{E}-3$ & $1.00 \mathrm{E} 1$ \\
\hline Polychaete worm & $3.84 \mathrm{E}-4$ & $2.39 \mathrm{E}-5$ & $1.00 \mathrm{E} 1$ \\
\hline Zooplankton & $1.65 \mathrm{E}-5$ & $1.24 \mathrm{E}-4$ & $1.00 \mathrm{E} 1$ \\
\hline
\end{tabular}

Although the strong environment issue related to Jakarta Bay such as land base source of pollution from industrial activities, the possible impact of 
RSG GAS 30 MW located at Serpong did not appeare on the surface at public domains. In addition, regulations that concern to protective impact from radionuclides in marine environment is still very limited. Some regulations were presented in Table 5. In fact, RSG GAS $30 \mathrm{MW}$ were operates for 104 days. There isn't potential release liquid waste since no waste dilution policy. Due to limited number nuclear activity on research and development or nuclear application in Indonesia, the potential release of anthropogenic radionuclides to environment only in small quantity. Radioactive waste were managed in installation of radioactive waste management.

Table 5. Nuclear regulations related to the presence of radioactive substance in environment

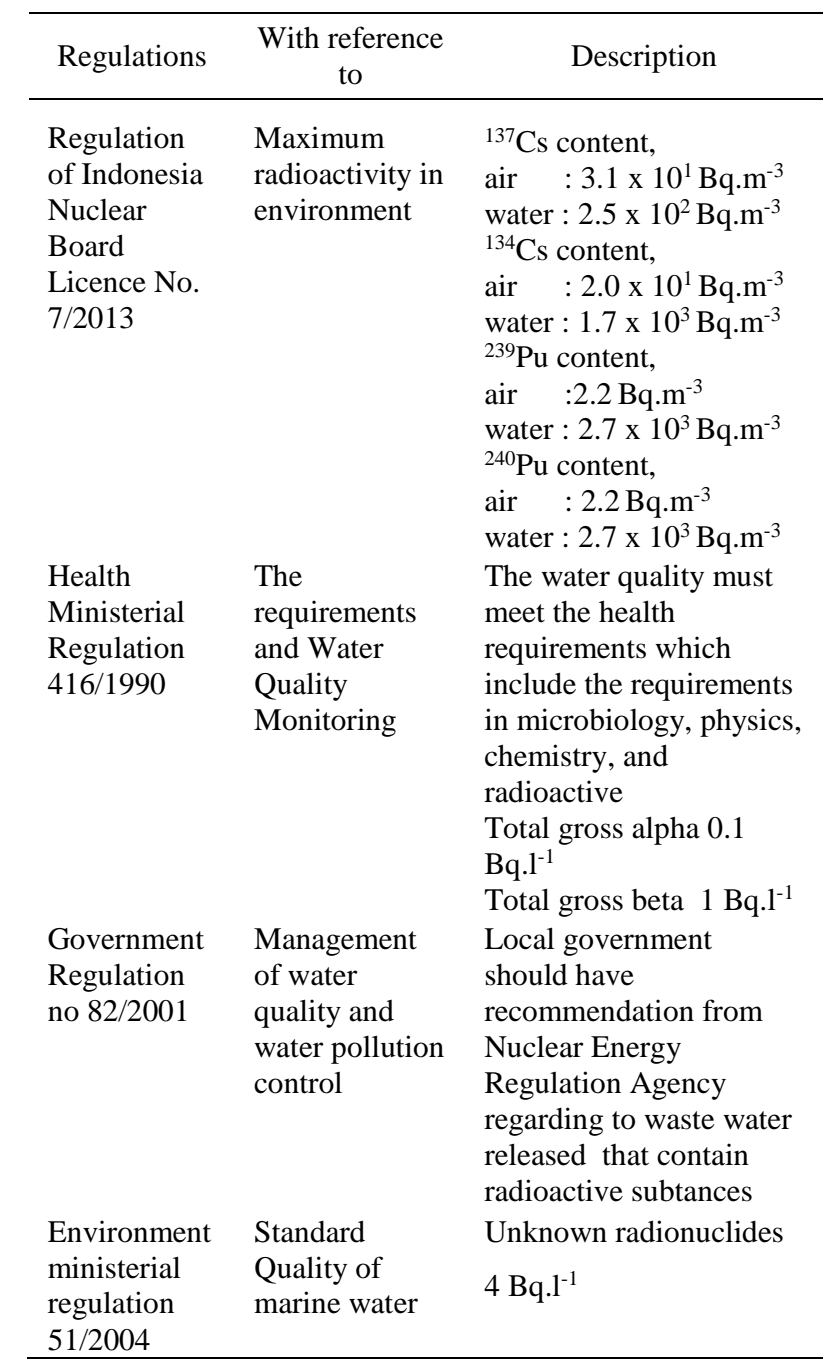

Some researches of environmental radionuclides monitoring have been performed near RSG GAS $30 \mathrm{MW}$ site. The amount of $2,91 \times 10^{-6} \mathrm{Ci}_{\text {.year }}{ }^{-1}$ were estimated to be released from reactor stack that calculated from source term [20]. Furthermore, another study reported that quantity of ${ }^{137} \mathrm{Cs}$ released from reactor does not exceed to source term [20]. In contrast, according to the Safety Analysis Report (SAR) of RSG GAS $30 \mathrm{MW}$ in Serpong have potential to release about 1.07 X $10^{5}$ Bq. $y^{-1}[20]$. The potential release of ${ }^{137} \mathrm{Cs}$ (source term) from reactor stack and result of measurement were presented in Table 6 . Radiocesium will be released from reactor stack to the atmosphere and then it was dispersed by the wind until deposited around nuclear area through the dry and wet deposition processes. Radiocesium will be run off frm soil to Cisadane river and finally entered to Jakarta Bay. Based on Source Term, Safety Analysis Report (SAR) and monitoring data, the estimation of ${ }^{137} \mathrm{Cs}$ entering to Jakarta Bay was maximum $1.07 \mathrm{X} 10^{5} \mathrm{~Bq}$ per year. The radiocesium released will dilute in river water and sea water in Jakarta Bay.

Table 6. Potential radioactivity released from Serpong Nuclear Research Center

\begin{tabular}{clc}
\hline $\begin{array}{c}\text { Realease } \\
\text { radioactive }\end{array}$ & \multicolumn{1}{c}{ Radionuclides } & References \\
\hline Measurement & $\begin{array}{l}{ }^{137} \text { Cs release from Stack of } \\
\text { Nuclear Research Reactor: } \\
\text { below 2.91X 10 } 0^{-6} \text { Ci.year }^{-1}\end{array}$ & 20 \\
Estimation & $\begin{array}{l}\text { Release from reactor stack } \\
\text { were estimated from } \\
\text { source term 2.91X 10 }\end{array}$ & 20 \\
& $\begin{array}{l}\text { Ci.year } \\
\text { - }\end{array}$ \\
& $\begin{array}{l}\text { Potential release according } \\
\text { to Safety Analysis Report } \\
\text { (SAR) of RSG GAS 30 }\end{array}$ & \\
MW 1.07 X 10 Bq. & 20 \\
\hline
\end{tabular}

Due to analysis by gamma spectrometer did not detect the ${ }^{134} \mathrm{Cs}$ it means the presences of ${ }^{137} \mathrm{Cs}$ in Jakarta Bay did not originated from RSG GAS. It is can be explained that finger print of radionuclides in surface water and sediment from global fall out were the concentration ratio of $\mathrm{Pu} / \mathrm{Cs}$. The ratio in surface water and sedimen were below 0.002 and 0.02-0.5 respectively [17]. We found the ratio concentration of $\mathrm{Pu} / \mathrm{Cs}$ in sea water and surface sediment were below 0.002 and 0.03 so that is was known that the radionuclides in Jakarta Bay were originated from global fall out.

\section{CONCLUSION}

The baseline level of ${ }^{137} \mathrm{Cs}$ in sea water and sea sediments were range 0.17-1.17 Bq. ${ }^{-3}$ and $0.34-1.21$ Bq.kg ${ }^{-1}$ respectivly. Result of ${ }^{239 / 240} \mathrm{Pu}$ measurement show that concentration at sea water and sea sediment were range from $<$ MDA-0.53 mBq. $\mathrm{m}^{-3}$ and 2.64-55.70 mBq. $\mathrm{kg}^{-1}$, 
respectively. The results of risk analysis were indicated that all the total dose rates per organism were millions time lower than the screening rate $\left(10 \mathrm{mGy} \cdot \mathrm{h}^{-1}\right)$. Anthropogenic radionuclides such as ${ }^{137} \mathrm{Cs}$ and ${ }^{239 / 240} \mathrm{Pu}$ in Jakarta Bay were originated from global fall out.

\section{ACKNOWLEDGMENT}

This research was supported by annual budget of Center Technology for Radiation Safety and Metrology, National Nuclear Energy Agency for RDE baseline data project at Jakarta Bay, fiscal year of 2016.

\section{REFERENCES}

1. D.F.R. Cleary, A.R.M. Polónia, W. Renema et al., Mar. Pollut. Bull. 110 (2016) 701. http://dx.doi.org/10.1016/j.marpolbul.2016.04.

2. A. Breckwoldt, L. Dsikowitzky, G. Baum et al., Mar. Pollut. Bull. 110 (2016) 790. doi: 10.1016/j.marpolbul.2016.08.040.

3. V.S.P Oetama, P. Hennersdorf, M.A. AbdulAziz et al., Mar. Pollut. Bull. 110 (2016) 718. https://doi.org/10.1016/j.marpolbul.2016.03.043

4. S.A. Wulp, L. Dsikowitzky, K. Jürgen et al., Mar. Pollut. Bull. 110 (2016) 686. http://dx.doi.org/10.1016/j.marpolbul.2016.05. 048

5. H. Suseno and H. Umbara, Radioactive Monitoring at Jakarta Bay and Muria Peninculla Coastal Zone, Proceeding of International Conference on Isotopic and Nuclear Analytical Techniques for Health and Environment (2004) 335.

6. Muslim, H. Suseno and S. Saodah, Indonesian Journal of Marine Sciences 21 (2016) 143. doi: 10.14710/ik.ijms.21.3.143-150

7. B.J. Howard, N.A. Beresford, D. Copplestone et al., J. Environ. Radioact. 121 (2013) 55. doi:10.1016/ j.jenvrad.2012.01.027

8. I. Levy, P.P. Povinec, M. Aoyama et al., J. Pocean 89 (2011) 120. doi:10.1016/j.pocean.2010.12.012
9. J.I. Tsuboi, S.I. Abe, K. Fujimoto et al., J. Environ. Radioact. 141 (2015) 32. http://dx.doi.org/10.1016/j.jenvrad.2014.11.012

10. H. Suseno, I.B. Wahono, M. Muslim et al., J. Reg. Stud. in Mar. Sci 10 (2017) 81. http://dx.doi.org/10.1016/j.rsma.2016.12.008

11. H. Suseno, I.B. Wahono and Muslim, Mar. Pollut. Bull. 97 (2015) 539. http://dx.doi.org/10.1016/j.marpolbul.2015.05. 015

12. D.J. Rowan, J. Environ. Radioact. 121 (2013) 2. doi:10.1016/j.jenvrad.2012.03.008

13. H. Suseno and W.R. Prihatiningsih, Mar. Pollut. Bull. 88 (2014) 319. http://dx.doi.org/10.1016/j.marpolbul.2014.08. 024

14. M.A. Ashraf, S. Akib, M. Maah et al., Crit. Rev. Environ. Sci. Technol. 44 (2014) 1740. doi: 10.1080/10643389.2013.790753

15. R. Periaez, S. Kyung-Suk and M. Byung-Il, J. Radioanal. Nucl. Chem. 2 (2012) 2. doi: 10.1007/s10967-013-2422-1

16. W. Bu, J. Zheng, T. Aono et al., Biogeosciences 10 (2013) 2497. doi:10.5194/bg-10-2497-2013

17. W. Bu, J. Zheng and G. Qiuju et al., J. Chromatogr. A 1337 (2014) 171. http://dx.doi.org/10.1016/j.chroma.2014.02.066

18. M.B. Froehlich, W.Y. Chan, S.G. Tims et al., J. Environ. Radioact. 165 (2016) 197. doi: 10.1016/j.jenvrad.2016.09.015

19. G. Lujaniene, N. Remeikait-Nikiene, G. Garnaga et al., J. Environ. Radioact. 127 (2014) 40. http://dx.doi.org/10.1016/ j.jenvrad.2013.09.013

20. J. Sudiyati, U. Hartoyo, N. Luhur et al., Determination Non of Source Term For An Annual Stack Release of Gas Reactor G.A. Siwabessy, Proceeding of National Seminar of Waste Management VI (2008) 228. (in Indonesian) 